\title{
Heat-Shock Protein Expression and Oxidative Stress in Male Infertility
}

\author{
Adel Zalata ${ }^{1}$, Nariman K.Badr El-din ${ }^{2}$, Hussein Abdelaziz Abdalla ${ }^{1}$ \\ and Mahmoud El-shahat ${ }^{2}$ \\ ${ }^{\mathbf{1}}$ Medical Biochemistry, Faculty of Medicine. ${ }^{2}$ Zoology Dept., \\ Faculty of Science - Mansoura University
}

\begin{abstract}
In infertile men, it has been demonstrated that heat shock protein (HspA2) is expressed in spermatogonia parallel the loss of spermatogenic function. Low level of HspA2 expression in spermatogonia might lead to an altered level of protection, which in turn could be involved in low spermatogenic efficiency. Aim: The present study aimed to investigate the relationship between expression of heat shock protein (HspA2) in ejaculated human sperm and oxidative stress in male infertility. Patients \& Methods: This study included 96 men attending the Andrology Outpatient Clinic, Mansoura University Hospital. The semen samples obtained from men were grouped according to WHO criteria into: Normozoospermia (N) was used as control group $(n=24)$, Asthenozoospermia $(A)(n=21)$, Astheno-Teratozoospermia $(A T)(n=23)$ and Oligo-Astheno-Teratozoospermia (OAT) $(n=28)$. Computer assisted semen analysis (Autosperm), hypo-osmotic swelling (HOS) test and acrosin activity of spermatozoa by gelatinolysis test were performed. Also, malondialdehyde (MDA)/spermatozoa and total antioxidant capacity (TAC) were assessed in seminal plasma. Expression level of HspA2 mRNA of spermatozoa was determined by RT-PCR and DNA fragmentation was detected by agarose gel electrophoresis. Result: The current study showed that, percentage of DNA fragmentation was significantly increased in OAT group compared to control group $(N)$. Also, the present study showed significantly negative correlation between MDA/spermatozoa with sperm concentration, grade A motility grade $A+B$ motility, velocity, linear velocity linearity index, normal morphology, acrosin activity index, HOS test TAC and HspA2 expression. HspA2 expression and TAC level showed significantly positive correlation with sperm concentration, grade A motility, grade $A+B$ motility, velocity, linear velocity, linearity index, normal morphology, acrosin activity index, HOS test and HspA2 expression. Conclusion: From results of the current study, it could be concluded that HspA2 gene expression in ejaculated sperm from infertile might be associated with spermatogenic and/or spermiogenic dysfunction involved in the pathogenesis of some cases of male infertility.
\end{abstract}

\section{INTRODUCTION}

It is estimated that about $15 \%$ of couples present with reduced fertility, and male infertility is responsible for half of these cases. The reduction in sperm count is generally accompanied with high rate of sperm with abnormal 
morphology and/or low progressive motility, which leads to lower fertility ${ }^{(\mathbf{1})}$.

Of the many causes of male infertility, oxidative stress (OS) has been identified as one factor that affects fertility status and thus, has been extensively studied. Spermatozoa, like any other aerobic cell, are constantly facing the "oxygen-paradox"(2). The presence of seminal oxidative stress in infertile men suggests its role in the pathophysiology via several mechanisms acting in synergism which can impair sperm characteristics and functional capacity $^{(3)}$.

Much remains to be learned about the regulation of gene expression during spermatogenesis process. Some developmentally regulated genes are expressed exclusively in spermatogenic germ cells, whereas others are expressed in both germ cells and somatic cells. Some of these genes expressed only in germ cells are homologues of genes transcribed in somatic cells and are members of specific gene families ${ }^{(4)}$, such as the heat-shock proteins (Hsps) families, which are highly conserved cellular stress proteins, present in every organism from bacteria to man ${ }^{(5)}$.

The HspA2, a member of the 70$\mathrm{kDa}$ Hsp family, is a molecular chaperone that assists in the folding, transport and assembly of proteins in the cytoplasm, mitochondria and endoplasmic reticulum ${ }^{(6)}$. Hsps have a protective action on the cellular autoregulation in response to an array of insults, including oxidative stress $^{(5)}$ and on the mechanism of homeostasis, providing a balance between protein synthesis and degradation ${ }^{(7)}$. The protective action of $\mathrm{HspA} 2$ could be mediated by anti-apoptotic, antiinflammatory and anti-DNA damage effects ${ }^{(8)}$.

During spermatogenesis, three distinct phases can be differentiated: mitotic proliferation of spermatogonia, meiotic development of spermatocytes, and postmeiotic development of spermatids and maturation of the spermatozoon ${ }^{(9)}$. Since all these developmental stages represent situations where dramatic transformations and cellular differentiation take place, it is not astonishing that spermatogenesis is accompanied by expression of different Hsps ${ }^{(10)}$.

HspA2 has an essential role for normal spermatogenesis.

Dysfunctional expression of regulated genes may result in abnormal spermatogenesis (11). In maturation arrest, testes $\mathrm{HspA} 2$ protein levels were shown to be lower than those in normal men and are completely absent in testes with Sertoli cell-only syndrome. The authors also demonstrated that HspA2 is expressed during the spermatocyte and spermatid stages of spermatogenesis $^{(12)}$. These results agree with those of Son et al. ${ }^{(13)}$, who demonstrated repression of HspA2 mRNA in testicular biopsy material from men with abnormal spermatogenesis.

In the current study, the relationship between the expression of heat shock protein HspA2 in ejaculated human sperm and oxidative stress in male infertility was investigated. 


\section{MATERIALS \& METHODS}

Study included 96 semen samples obtained from patients attending the Andrology Outpatient's Clinic, Mansoura University Hospital, Egypt. The semen samples were grouped according to criteria of WHO into, Normozoospermia $\quad(\mathrm{n}=24)$, Asthenozoospermia $(\mathrm{n}=21)$, AsthenoTeratozoospermia $(\mathrm{n}=23)$ and OligoAstheno-Teratozoospermia $\quad(\mathrm{n}=28)$. All semen samples were investigated for semen analyses and acrosin activity as described by Henkel et $\boldsymbol{a l} .^{(\mathbf{1 4})}$. Determination of malondialdehyde (MDA)/spermatozoa was assessed by the method of Draper et $\boldsymbol{a l} .{ }^{(15)}$. Total antioxidant capacity (TAC) of seminal plasma was measured by colorimetric method using commercially available kit (Cayman Chemicals, Ann Arbor, MI, USA) according to the method of Rice-Evans and Miller ${ }^{(16)}$. The results were expressed as $\mathrm{mM}$ Trolox equivalent.

Hypo-osmotic Swelling Test: 1 $\mathrm{ml}$ aliquot of swelling solution $(0.735$ g sodium citrate dihydrate and $1.351 \mathrm{~g}$ fructose dissolved in $100 \mathrm{ml}$ distilled water) was added to $0.1 \mathrm{ml}$ of liquefied semen and mixed well. Then the mixture was incubated at $37^{\circ} \mathrm{C}$ for 30 minutes $^{(\mathbf{1})}$ and sperms were then examined under phase-contrast microscope.
RT-PCR analyses: Total RNA was extracted from sperms using AxyPrep Multisource Total RNA Miniprep kit (Axygen Biosciences, Union City, CA 94587, USA). cDNA synthesis from total RNA and PCR was performed by RT/PCR Master Mix. Gold Beads Kits (BIORON The ENZYME company, Germany) using Open Reading Frame sequencespecific primers. $\beta$-actin: sense, 5'CGT GAC ATT AAG GAG AAG CTG TGC-3'; antisense, 5'-CTC AGG AGG AGC AAT GAT CTT GAT-3', and HspA2: sense, 5'-TTG TTG GAA GTC TTT GGT ATA-3' and antisense, 5'-CAT TTG CAT TTA TGC ATT TGT-3'(13). PCR was performed by heating for $10 \mathrm{~min}$. at $94^{\circ} \mathrm{C}$ for DNA denaturation followed by 36 cycles $\left(1 \mathrm{~min}\right.$. at $94^{\circ} \mathrm{C}, 1 \mathrm{~min}$. at $57^{\circ} \mathrm{C}, 1 \mathrm{~min}$. at $72^{\circ} \mathrm{C}$ ) and a final extension for $10 \mathrm{~min}$. at $72^{\circ} \mathrm{C}$. The cDNA amplification was assessed on $2 \%$ agarose gel by electrophoresis ${ }^{(17)}$. The gel was analyzed with image analysis as it was possible to estimate comparatively the amount of cDNA (semiquantified) referring to the genes under study. The cDNA amplifications of each sample were assessed for the $\beta$-actin and HspA2 genes. The samples were first analyzed for $\beta$-actin, which characterizes the presence of total RNA in the material under study, and then for HspA2. The HspA2/ $/$-actin ratio was assessed in all groups (Figure 1). 


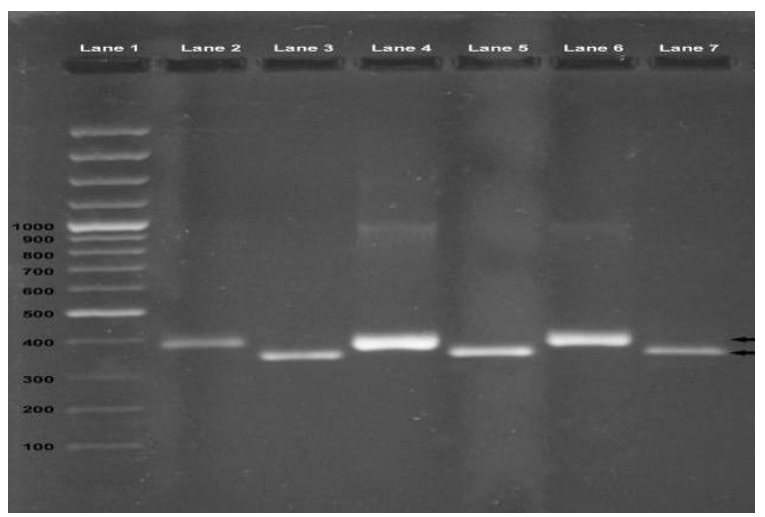

Fig. (1): RT-PCR detection of HspA2 and $\beta$-actin mRNA expression in RNA isolated from ejaculated spermatozoa. Lane 1 shows molecular weight marker (in base pairs), lane 2, 4 and 6 show HspA2 mRNA expression and lanes 3, 5 and 7 show $\beta$-actin mRNA expression.

DNA Fragmentation Analysis by Agarose Gel Electrophoresis ${ }^{(18)}$ :

Spermatozoa were collected after centrifugation and DNA fragmentation was assessed by Enhanced Apoptotic DNA Ladder Detection kit (BioVision Research Products 980 linda ista Avenue, Mountain View, CA 94043 .USA). Sperm pellet $5-10 \times 10^{6}$ cells in a 1.5 $\mathrm{ml}$ microcentrifuge tube was washed with PBS and the pellet was centrifuged for $5 \mathrm{~min}$ at $500 \mathrm{x} \mathrm{g}$. Supernatant was removed and the cells were lysed with $35 \mu \mathrm{l}$. TE lysis buffer. $5 \mu$ l of enzyme A solution were added and mixed by gentle vortex and incubated at $37^{\circ} \mathrm{C}$ for 10 min. $5 \mu 1$ of enzyme B solution were added into each sample and incubated at $50^{\circ} \mathrm{C}$ for $30 \mathrm{~min}$. Also, $5 \mu \mathrm{l}$ of 9843 ammonium acetate solution and $50 \mu \mathrm{l}$ of isopropanol were added and mixed well. DNA pellet was washed with $0.5 \mathrm{ml} 70 \%$ ethanol, and air dried. The DNA pellet was dissolved in $20 \mu$ l DNA suspension buffer. The sample was loaded onto a $1.8 \%$ agarose gel. The gel was run at 5 $\mathrm{V} / \mathrm{cm}$ for 1 hour. The gel was stained by staining buffer (provided by the kit) with gentle shaking for 30 minutes. DNA ladder was visualized by illumination of short UV wavelength $(254 \mathrm{~nm}) \quad$ and photographed with camera equipped with $520 \mathrm{~nm}$ filter (Figure 2). 


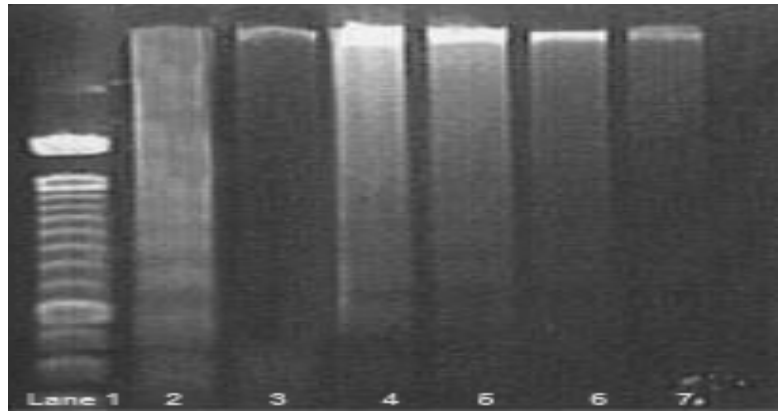

Figure (2): Analysis of genomic DNA fragmentation in human spermatozoa (sperm pellet $10 \times 10^{6}$ cells) from different groups. Total DNA from spermatozoa was prepared, and fragmentation was assessed by agarose gel electrophoresis. Lane 1: 100-bp ladder (GIBCO-BRL). Lanes 2, 4, 5: show DNA fragmentation (DNA ladder), lanes 3, 6, 7: show no DNA fragments (no DNA ladder).

\section{Statistical analysis}

Statistical analysis was performed using the MedCalc program (MedCalc Software, Mariakerke, Belgium $)^{(\mathbf{1 9})}$. The significance of differences between groups was assessed using Wilcoxon's test. Correlations were calculated using Spearman's rank order coefficient. $\mathrm{P}$ value of $<0.05$ was considered statistically significant.

\section{RESULTS}

The sperm characteristics exhibited by all groups are given in Table 1.

Table (1) Semen parameters in all studied groups (Median, Range):

\begin{tabular}{|c|c|c|c|c|}
\hline Parameters & $\mathrm{N}$ n=24 & $\mathbf{A} \mathbf{n}=\mathbf{2 1}$ & AT $n=23$ & OAT n=28 \\
\hline Volume (ml) & $\begin{array}{l}3.0 \\
(2.0-7.0)\end{array}$ & $\begin{array}{l}3.5 \\
(1.0-7.5)\end{array}$ & $\begin{array}{l}3.0 \\
(1.0-8.2)\end{array}$ & $\begin{array}{c}3.7 \\
(1.5-8.4)\end{array}$ \\
\hline Concentration (million /ml) & $\begin{array}{l}67.2 \\
(44.8-96.0)\end{array}$ & $\begin{array}{l}49.5 \\
(24.9-67.2)\end{array}$ & $\begin{array}{l}29.5 \\
(20.8-53.3)\end{array}$ & $\begin{array}{l}4.7 \\
(0.4-18.6)\end{array}$ \\
\hline Grade A motility (\%) & $\begin{array}{l}54.0 \\
(41.0-60.0)\end{array}$ & $\begin{array}{l}33.0 \\
(14.0-42.0)\end{array}$ & $\begin{array}{l}14.0 \\
(0.0-28.0)\end{array}$ & $\begin{array}{l}2.5 \\
(0.0-20.0)\end{array}$ \\
\hline Grade A+B motility (\%) & $\begin{array}{l}60.0 \\
(51.0-67.0)\end{array}$ & $\begin{array}{l}39.0 \\
(35.0-57.0)\end{array}$ & $\begin{array}{l}28.0 \\
(2.0-44.0)\end{array}$ & $\begin{array}{l}10.0 \\
(0.0-41.0)\end{array}$ \\
\hline Velocity $(\mu \mathrm{m} / \mathrm{sec})$ & $\begin{array}{l}80.0 \\
(63.4-95.4)\end{array}$ & $\begin{array}{l}74.4 \\
(32.3-109.7)\end{array}$ & $\begin{array}{l}36.4 \\
(17.6-69.9)\end{array}$ & $\begin{array}{l}22.1 \\
(0.0-74.5)\end{array}$ \\
\hline Linear velocity $(\mu \mathrm{m} / \mathrm{Sec})$ & $\begin{array}{l}61 \\
(42.9-70.7) \\
\end{array}$ & $\begin{array}{l}50.8 \\
(18.1-84.1) \\
\end{array}$ & $\begin{array}{l}23 \\
(11.1-49.4)\end{array}$ & $\begin{array}{l}11.8 \\
(0.0-52.6)\end{array}$ \\
\hline Linearity index ( \%) & $\begin{array}{l}76.9 \\
(67.5-86.7) \\
\end{array}$ & $\begin{array}{l}65.8 \\
(43.3-77.6) \\
\end{array}$ & $\begin{array}{l}60.8 \\
(48.7-86.5) \\
\end{array}$ & $\begin{array}{l}63.5 \\
(0.0-97.4) \\
\end{array}$ \\
\hline Normal morphology (\%) & $\begin{array}{l}64.0 \\
(58.0-66.0)\end{array}$ & $\begin{array}{l}44.0 \\
(34.0-64.0)\end{array}$ & $\begin{array}{l}12.0 \\
(2.0-22.0)\end{array}$ & $\begin{array}{l}2.0 \\
(0.0-10.0)\end{array}$ \\
\hline WBCs (million/ml) & $\begin{array}{l}0.5 \\
(0.4-0.6)\end{array}$ & $\begin{array}{l}0.6 \\
(0.4-3.6)\end{array}$ & $\begin{array}{l}0.8 \\
(0.4-4.4)\end{array}$ & $\begin{array}{l}0.7 \\
(0.3-3.6)\end{array}$ \\
\hline
\end{tabular}

$\mathbf{N}=$ Normozoospermia, $\mathbf{A}=$ Asthenozoospermia, $\mathbf{A T}=$ Astheno-Teratozoospermia, $\mathbf{O A T}=$ Oligo-Astheno-Teratozoospermia and $\mathbf{n}=$ number of cases 
Table (2): Acrosin activity index, HOST (\%), MDA/spermatozoa, and TAC in all studied groups (median, range)

\begin{tabular}{|c|c|c|c|c|c|}
\hline Parameter & $\mathrm{N} n=24$ & A $n=21$ & AT $\mathbf{n}=\mathbf{2 3}$ & OAT $n=28$ & p-value \\
\hline $\begin{array}{l}\text { Acrosin activity } \\
\text { index }\end{array}$ & $\begin{array}{c}12.6 \\
(8.9-19.4)\end{array}$ & $\begin{array}{c}10.7 \\
(5.5-13.9)\end{array}$ & $\begin{array}{c}5.0 \\
(0.9-11.0)\end{array}$ & $\begin{array}{c}2.2 \\
(0.6-7.5)\end{array}$ & $\begin{array}{l}\mathrm{P} 1<0.0001 \\
\mathrm{P} 2<0.0001 \\
\mathrm{P} 3<0.0001\end{array}$ \\
\hline HOST (\%) & $\begin{array}{c}84.0 \\
(72.0-94.0)\end{array}$ & $\begin{array}{c}62.0 \\
(48.0-89.0)\end{array}$ & $\begin{array}{c}54.0 \\
(32.0-67.0)\end{array}$ & $\begin{array}{c}33.5 \\
(6.0-65.0)\end{array}$ & $\begin{array}{l}\mathrm{P} 1<0.0001 \\
\mathrm{P} 2<0.0001 \\
\mathrm{P} 3<0.0001\end{array}$ \\
\hline MDA/spermatozoa & $\begin{array}{c}3.00 \\
(1.40-6.58)\end{array}$ & $\begin{array}{c}5.48 \\
(2.01-14.36)\end{array}$ & $\begin{array}{c}7.57 \\
(2.17-16.65)\end{array}$ & $\begin{array}{c}50.84 \\
(9.47-521.73)\end{array}$ & $\begin{array}{l}\mathrm{P} 1=0.0005 \\
\mathrm{P} 2<0.0001 \\
\mathrm{P} 3<0.0001\end{array}$ \\
\hline $\begin{array}{l}\text { TAC } \\
\text { (mM Trolox } \\
\text { equivalent) }\end{array}$ & $\begin{array}{c}1.8 \\
(1.2-2.6)\end{array}$ & $\begin{array}{c}1.4 \\
(0.9-1.8)\end{array}$ & $\begin{array}{c}1.2 \\
(0.6-1.7)\end{array}$ & $\begin{array}{c}0.9 \\
(0.7-1.4)\end{array}$ & $\begin{array}{l}\mathrm{P} 1=0.0001 \\
\mathrm{P} 2<0.0001 \\
\mathrm{P} 3<0.0001\end{array}$ \\
\hline
\end{tabular}

$\mathbf{P}_{1}$ : significance between $\mathrm{N}$ and $\mathrm{A}, \mathbf{P}_{2}$ : significance between $\mathrm{N}$ and $\mathrm{AT}$ and $\mathbf{P}_{3}$ : significance between $\mathrm{N}$ and OAT

Table (2) shows the acrosin activity index, HOS test (\%), malondialdehyde (MDA) $\left(\mathrm{nmol} / 10^{8}\right.$ sperm) and TAC (mM Trolox equivalent) in all studied groups. Acrosin activity index, HOS test and total antioxidant capacity were significantly higher in control (N) group compared with A, AT and OAT groups. However, seminal plasma concentration of malondialdehyde (MDA) per $10^{8}$ sperm was significantly increased in A, AT and OAT groups than in the control $(\mathrm{N})$ group.

Table (3): DNA fragmentation of spermatozoa and HspA2 expression among different groups.

\begin{tabular}{|l|l|l|l|l|l|}
\hline Parameter & $\mathbf{N} \mathbf{n = 2 4}$ & $\mathbf{A} \mathbf{n = 2 1}$ & $\mathbf{A T} \mathbf{n = 2 3}$ & $\mathbf{O A T ~} \mathbf{n = 2 8}$ & $\mathbf{p - v a l u e}$ \\
\hline $\begin{array}{l}\text { DNA } \\
\text { fragmentation (\%) }\end{array}$ & $\begin{array}{l}3 / 24 \\
(12.5 \%)\end{array}$ & $\begin{array}{l}5 / 21 \\
(23.8 \%)\end{array}$ & $\begin{array}{l}9 / 23 \\
(39.1 \%)\end{array}$ & $\begin{array}{l}14 / 28 \\
(50 \%)\end{array}$ & $\begin{array}{l}\mathrm{P} 1=0.5496 \\
\mathrm{P} 2=0.0790 \\
\mathrm{P} 3=0.0100\end{array}$ \\
\hline HspA2 expression & $\begin{array}{l}2.50 \\
(1.40-3.57)\end{array}$ & $\begin{array}{l}1.29 \\
(0.92-1.54)\end{array}$ & $\begin{array}{l}0.92 \\
(0.74-1.19)\end{array}$ & $\begin{array}{l}0.69 \\
(0.41-1.08)\end{array}$ & $\begin{array}{l}\mathrm{P} 1<0.0001 \\
\mathrm{P} 2<0.0001 \\
\mathrm{P} 3<0.0001\end{array}$ \\
\hline
\end{tabular}

Table (3) shows DNA fragmentation\% and HspA2 expression in all studied groups. The DNA fragmentation \% was significantly increased in OAT group compared to control. HspA2 expression was significantly lower in A, AT \& OAT compared to control group $(\mathrm{N})$. 
Table (4): Correlation of MDA/spermatozoa, TAC and HspA2 expression with sperm parameters $(n=96)$.

\begin{tabular}{|c|c|c|c|}
\hline Parameter & $\begin{array}{c}\text { MDA/ } \\
\text { spermatozoa }\end{array}$ & $\begin{array}{c}\text { TAC } \\
\text { (mM Trolox } \\
\text { equivalent) }\end{array}$ & $\begin{array}{c}\text { HspA2 } \\
\text { Expression }\end{array}$ \\
\hline $\begin{array}{l}\text { Concentration (million } / \mathrm{ml} \text { ) } \\
-\mathrm{r} \\
-\mathrm{P}\end{array}$ & $\begin{array}{c}-0.913 \\
\mathrm{P}<0.0001\end{array}$ & $\begin{array}{c}0.728 \\
\mathrm{P}<0.0001\end{array}$ & $\begin{array}{c}0.779 \\
\mathrm{P}<0.0001\end{array}$ \\
\hline $\begin{array}{l}\text { Grade A motility }(\%) \\
-r \\
-P\end{array}$ & $\begin{array}{c}-0.860 \\
P<0.0001\end{array}$ & $\begin{array}{c}0.709 \\
\mathrm{P}<0.0001\end{array}$ & $\begin{array}{c}0.771 \\
\mathrm{P}<0.0001\end{array}$ \\
\hline $\begin{array}{l}\text { Grade A+B motility (\%) } \\
-\mathbf{r} \\
-\mathrm{P}\end{array}$ & $\begin{array}{c}-0.809 \\
\mathrm{P}<0.0001\end{array}$ & $\begin{array}{c}0.713 \\
\mathrm{P}<0.0001\end{array}$ & $\begin{array}{c}0.757 \\
\mathrm{P}<0.0001\end{array}$ \\
\hline $\begin{array}{l}\text { Velocity }(\mu \mathrm{m} / \mathrm{sec}) \\
-\mathrm{r} \\
-\mathrm{P}\end{array}$ & $\begin{array}{c}-0.783 \\
P<0.0001\end{array}$ & $\begin{array}{c}0.664 \\
P<0.0001\end{array}$ & $\begin{array}{c}0.667 \\
\mathrm{P}<0.0001\end{array}$ \\
\hline $\begin{array}{l}\text { Linear velocity }(\mu \mathrm{m} / \mathrm{Sec}) \\
-\mathrm{r} \\
-\mathrm{P}\end{array}$ & $\begin{array}{c}-0.814 \\
\mathrm{P}<0.0001\end{array}$ & $\begin{array}{c}0.655 \\
\mathrm{P}<0.0001\end{array}$ & $\begin{array}{c}0.700 \\
\mathrm{P}<0.0001\end{array}$ \\
\hline $\begin{array}{l}\text { Linearity index (\%) } \\
-r \\
-P\end{array}$ & $\begin{array}{c}-0.417 \\
\mathrm{P}<0.0001\end{array}$ & $\begin{array}{c}0.335 \\
\mathrm{P}=0.0009\end{array}$ & $\begin{array}{c}0.386 \\
\mathrm{P}=0.0001\end{array}$ \\
\hline $\begin{array}{l}\text { Normal morphology }(\%) \\
-r \\
-\mathrm{P} \\
\end{array}$ & $\begin{array}{c}-0.838 \\
\mathrm{P}<0.0001\end{array}$ & $\begin{array}{c}0.741 \\
\mathrm{P}<0.0001\end{array}$ & $\begin{array}{c}0.811 \\
\mathrm{P}<0.0001\end{array}$ \\
\hline $\begin{array}{l}\text { WBCs (million/ml) } \\
-\mathrm{r} \\
-\mathrm{P}\end{array}$ & $\begin{array}{c}0.346 \\
\mathrm{P}=0.0006\end{array}$ & $\begin{array}{c}-0.293 \\
\mathrm{P}=0.0037\end{array}$ & $\begin{array}{c}-0.407 \\
\mathrm{P}<0.0001\end{array}$ \\
\hline $\begin{array}{l}\text { Acrosin activity index } \\
-r \\
-P\end{array}$ & $\begin{array}{c}-0.767 \\
P<0.0001\end{array}$ & $\begin{array}{c}0.679 \\
\mathrm{P}<0.0001\end{array}$ & $\begin{array}{c}0.763 \\
\mathrm{P}<0.0001\end{array}$ \\
\hline $\begin{array}{l}\text { HOST (\%) } \\
-\mathbf{r} \\
-\mathrm{P} \\
\end{array}$ & $\begin{array}{c}-0.764 \\
\mathrm{P}<0.0001 \\
\end{array}$ & $\begin{array}{c}0.724 \\
\mathrm{P}<0.0001 \\
\end{array}$ & $\begin{array}{c}0.734 \\
\mathrm{P}<0.0001\end{array}$ \\
\hline $\begin{array}{l}\text { MDA/spermatozoa } \\
-\mathrm{r} \\
-\mathrm{P}\end{array}$ & 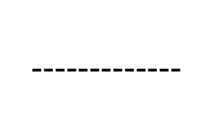 & $\begin{array}{c}-0.678 \\
\mathrm{P}<0.0001\end{array}$ & $\begin{array}{c}-0.707 \\
\mathrm{P}<0.0001\end{array}$ \\
\hline $\begin{array}{l}\text { TAC } \\
-\mathbf{r} \\
-\mathbf{P}\end{array}$ & $\begin{array}{c}-0.678 \\
\mathrm{P}<0.0001\end{array}$ & -------------- & $\begin{array}{c}0.718 \\
\mathrm{P}<0.0001\end{array}$ \\
\hline $\begin{array}{l}\text { HspA2 Expression } \\
-r \\
-P\end{array}$ & $\begin{array}{c}-0.707 \\
\mathrm{P}<0.0001\end{array}$ & $\begin{array}{c}0.718 \\
\mathrm{P}<0.0001\end{array}$ & ------- \\
\hline
\end{tabular}


Table (4) shows the correlations between seminal MDA/spermatozoa, TAC (mM Trolox equivalent), HspA2 expression, and semen characters. This table shows significantly negative correlation between MDA/spermatozoa with sperm concentration, grade A motility, grade A+B motility, velocity, linear velocity, linearity index, normal morphology, acrosin activity index, HOS test, TAC and HspA2 expression. Significant positive correlation was shown between MDA/spermatozoa and WBCs.

HspA2 expression and TAC level showed significantly positive correlation with sperm concentration, grade A motility, grade A+B motility, velocity, linear velocity, linearity index, normal morphology, acrosin activity index, HOS test and HspA2 expression.

Table (5): acrosin activity index, HOST (\%), MDA/spermatozoa, TAC and HspA2 expression in samples without and with DNA fragmentation. (median, range)

\begin{tabular}{|c|c|c|c|}
\hline Parameter & $\begin{array}{c}\text { Samples without } \\
\text { DNA } \\
\text { fragmentation } \\
(n=55)\end{array}$ & $\begin{array}{c}\text { Samples with } \\
\text { DNA } \\
\text { fragmentation } \\
(n=25)\end{array}$ & $\begin{array}{l}\text { Significant } \\
\text { comparison }\end{array}$ \\
\hline Acrosin activity index (\%) & $\begin{array}{c}8.98 \\
(0.62-19.49)\end{array}$ & $\begin{array}{c}3.26 \\
(0.72-17.25)\end{array}$ & $\mathrm{P}=0.0052$ \\
\hline $\operatorname{MDA}(\mathrm{nmol} / \mathrm{l}) / 10^{8}$ sperm $)$ & $\begin{array}{c}5.48 \\
(1.40-521.73)\end{array}$ & $\begin{array}{c}10.50 \\
(1.47-290.00)\end{array}$ & $\mathrm{P}=0.0212$ \\
\hline HOST (\%) & $\begin{array}{c}62.00 \\
(9.00-94.00)\end{array}$ & $\begin{array}{c}52.00 \\
(6.00-86.00)\end{array}$ & $\mathrm{P}=0.0548$ \\
\hline $\begin{array}{l}\text { TAC(mM Trolox } \\
\text { equivalent) }\end{array}$ & $\begin{array}{c}1.38 \\
(0.69-2.64)\end{array}$ & $\begin{array}{c}1.13 \\
(0.78-2.26)\end{array}$ & $\mathrm{P}=0.0327$ \\
\hline HspA2 expression & $\begin{array}{c}1.19 \\
(0.50-3.57)\end{array}$ & $\begin{array}{c}0.77 \\
(0.41-1.95)\end{array}$ & $\mathrm{P}<0.0001$ \\
\hline
\end{tabular}

Table (5) shows acrosin activity index, HOS test, TAC, and HspA2 expression decreased in samples with DNA fragmentation compared with samples without DNA fragmentation. However, MDA/spermatozoa was significantly increased in samples with DNA fragmentation than those samples without DNA fragmentation.

\section{DISCUSSION}

Heat shock proteins play a cytoprotective role in preventing irreversible damage to cellular proteins by binding to unfolded or partially malfolded peptides to retard thermal denaturation and aggregation of cellular proteins ${ }^{(20)}$. It is well demonstrated that some Hsp are expressed in normal conditions in the testis (21), some are developmentally regulated and some are only induced in response to an array of insults, including hyperthermia, oxidative stress, heavy metals, ethanol, amino acid analogues, inflammation and infection ${ }^{(5)}$. 
In the present study, semiquantitative RT-PCR analysis demonstrated a positive correlation between HspA2 expression and semen parameters in accordance with Son et al. ${ }^{(13)}$, who demonstrated repression of HspA2 mRNA in testicular biopsy material from men with abnormal spermatogenesis. Huszar et al. (22) have demonstrated that HspA2 is present in ejaculated human sperm. In addition, a lower expression of HspA2 was correlated with a higher percentage of cells with residual cytoplasm, determined by creatine kinase (CK) activity ${ }^{(23)}$. This suggests that HspA2 is essential for normal spermatogenesis, which is confirmed by the fact that lower HspA2/CK ratios correlate with lower fertility rates in in vitro fertilization programs $^{(24)}$. Naaby-Hansen and Herr ${ }^{\text {(25) }}$ have demonstrated that the constituency of HSP chaperones on the human sperm surface is far more diverse, abundant and immunogenically crossreactive than previously recognized, and suggested that plasma membrane-associated chaperones serve multiple functions in human sperm, some of which appear to be critical for sperm-ZP interaction and fertilization.

Feng et al. ${ }^{(12)}$ have reported that, HspA2 was expressed in spermatocytes and spermatids in normal testes and in cases with maturation arrest but that expression was decreased in the latter. These authors concluded that lower HspA2 expression might be associated with the pathogenesis of male infertility. Di Domenico et al. ${ }^{(26)}$ showed that the production of Hsp70 is quantitatively correlated with the degree of stress.
The level of synthesis is controlled both transcriptionally and posttranscriptionally through repression of Hsp70 mRNA synthesis and destabilization of Hsp70 transcripts.

Of the many causes of male infertility, is oxidative stress (OS) which result from imbalance between the production of ROS and the body's antioxidant defense mechanisms ${ }^{(27)}$. Although it has been shown that small amounts of ROS are essential for regulation of normal sperm functions like sperm capacitation, acrosome reaction and oocyte fusion ${ }^{(28)}$, but at high levels they have potential toxic effects on sperm quality and function.

The present data showed that MDA/spermatozoa in seminal fluid were significantly higher in patients with DNA fragmentation than those in patients without fragmentation. Meanwhile, in patients with DNA fragmentation, TAC and HspA2 expression were significantly decreased. These data were in accordance with previous studies that showed high production of ROS and low antioxidant capacity in infertile men with varicocele ${ }^{(29,30)}$. This study showed a high frequency of DNA fragmentation in patients with abnormal spermatogenesis that could be explained by the pathologic action of oxidative stress demonstrated by MDA per spermatozoa and the decreased level of protection demonstrated by HspA2 expression and total antioxidant Capacity. Because of the known association between sperm immaturity and increased rate of lipid peroxidation and fragmentation of DNA in men ${ }^{(31,32)}$, it could be hypothesized that both lipid peroxidation and DNA 
fragmentation are related to apoptosis in immature sperm.

In conclusion, the present study demonstrated that HspA2 gene expression was significantly downregulated in ejaculated sperm from infertile men sustain oxidative stress. Anomalies in the expression of that gene are associated with spermatogenic and/or spermiogenic dysfunction involved in the pathogenesis of some cases of male infertility, and sperm mRNA analyses may thus be a useful tool in evaluating the infertile man.

\section{Acknowledgement:}

The authors thank Dr. Moheiddin Alghobary from Dermatology and Venereology Departments for recruiting patients for this study from the Andrology Outpatient's Clinic, Mansoura University Hospital, Egypt.

\section{REFERENCES}

1. World Health Organization (WHO, 2010): WHO laboratory manual for the examination of human serum and sperm-cervical mucus interaction, $5^{\text {th }}$ ed. WHO Press, Geneva, Switzerland.

2. Sies H., (1993): Strategies of antioxidant defense. Eur. J. Biochem., 215: 213- 219.

3. Zalata A., Ahmed A., Allamaneni S., Comhaire F., Agarwal A. (2004): Relationship between acrosin activity of human spermatozoa and oxidative stress. Asian J. Androl., 6: 313318.

4. Eddy E. (1999): Role of heat shock protein HSP70-2 in spermatogenesis. Rev. Reprod., 4: 23-30.
5. Neuer A., Spandorfer S., Giraldo P., Dieterle S., Rosenwaks Z., and Witkin S. (2000): The role of heat shock proteins in reproduction. Hum. Reprod. Update 6:149-159.

6. Georgopoulos C., and WelchW. (1993): Role of the major heat shock proteins as molecular chaperones. Annu. Rev. Cell Biol., 9: 601-634.

7. Shi Y., Mosser D., and Morimoto R. (1998): Molecular chaperones as HSF1- specific transcriptional repressors. Genes Dev., 12: 654-666.

8. Matsuda M., Hoshino T., Yamashita Y., Tanaka K., Maji D., Sato K., Adachi H., Sobue G., Ihn H., Funasaka Y., and Mizushima T. (2010): Prevention of UVB radiationinduced epidermal damage by expression of Heat shock protein 70. The Journal of Biological Chemistry 285 (8): 5848-5858.

9. Ritossa F. (1962): A new puffing pattern induced by a temperature shock and DNP in Drosophila. Cellular and Molecular Life Sciences 18(12): 571-573.

10. Dix D. (1997): Hsp70 expression and function during gametogenesis. Cell Stress Chaperones 2: 73-77.

11. Eddy E., O'Brien D. and Welch J. (1991): Mammalian sperm development in vivo and in vitro. In Wassarman PM (ed.) Elements of Mammalian Fertilization, Vol. 1, CRC Press, Boca Raton, FL., pp: 1-28.

12. Feng H., Sandlow J. and Sparks A. (2001): Decreased expression of the heat shock protein hsp70-2 
is associated with the pathogenesis of male infertility. Fertil. Steril., 76: 1136-1139.

13. Son W., Han C., Hwang S., Lee J., Kim S., and Kim Y. (2000): Repression of hspA2 messenger RNA in human testes with abnormal spermatogenesis. Fertil. Steril., 73: 1138-1144.

14. Henkel R., Muller C., Miska W., Schill W., Kleinstein J., and Gips H. (1995): Acrosin activity of human spermatozoa by means of a simple gelatinolytic technique: a method useful for IVF. J. Androl., 16: 272-277.

15. Draper H., Squires E., Mahmoodi H., Wu J., Agarwal S., and Hadley M. (1993): A comparative evaluation of thiobarbituric acid methods for the determination of malondialdehyde in biological materials. Free Rad. Biol. Med., 15: $353-363$.

16. Rice-Evan C., and Miller $N$. (1994): Total antioxidant status in plasma and body fluids. Methods Enzymol., 234 (24): 279-293.

17. Cedenho A., Lima S., Cenedeze M., Spaine D., Ortiz V., and Oehninger S. (2006): Oligozoospermia and heat-shock protein expression in ejaculated spermatozoa. Human Reproduction 21 (7): 1791-1794.

18. Daniel P., Sturm I., Ritschel S., Friedrich K., Dörken B., Bendzko P., and Hillebrand $T$. (1999): Detection of genomic DNA fragmentation during apoptosis (DNA ladder) and the simultaneous isolation of RNA from low cell numbers.
Analytical Biochemistry 266:

110-115.

19. Schoonjans F., Zalata A., Depyudt C., and Comhaire F. (1995): MedCalc: a new computer program for medical statistics. Computer Methods and Programs in Biomedicine 48: 257-262.

20. Morimoto R., Tissieres A., and Georgopoulos C. (1994): The biology of heat shock proteins and molecular chaperones. Cold Spring Harbor Laboratory Press, Plainview, NY. pp: 34-56.

21. Wu Y., Pei Y., and Qin Y. (2011): Developmental expression of heat shock proteins $60,70,90$, and $\mathrm{A} 2$ in rabbit testis. Cell Tissue Res., 344: 355-363.

22. Huszar G., Stone K., Dix D., and Vigue L. (2000): Putative creatine kinase $\mathrm{M}$ - isoform in human sperm is identified as the 70-kilodalton heat shock protein HspA2. Biol. Reprod., 63: 925932.

23. Huszar G. and Vigue L. (1990): Spermatogenesis-related change in the synthesis of the creatine kinase B-type and M-type isoforms in human spermatozoa. Mol. Reprod. Dev., 25: 258-262.

24. Huszar G., Vigue L., and Morshedi M. (1992): Sperm creatine phosphokinase Misoform ratios and fertilizing potential of men: a blinded study of 84 couples treated with in vitro fertilization. Fertil. Steril., 57: 882-888.

25. Naaby-Hansen S., and Herr J. (2010): Heat shock proteins on the human sperm surface. Journal 
of Reproductive Immunology 84 : 32-40.

26. Di Domenico B., Bugaisky G. and Lindquist S. (1982): The heat shock response is selfregulated at both the transcriptional and posttranscriptional levels. Cell 31(3pt2): 593- 603.

27. Makker K., Agarwal A., and Sharma R. (2009): Oxidative stress and male infertility. Indian J. Med. Res., 129: 357-367.

28. Griveau J., Le Lannou D. (1997): Reactive oxygen species and human spermatozoa. Physiology and Pathology, 20: 61-69.

29. Hendin B., Kolettis P., Sharma R., Thomas A. Jr, and Agarwal A. (1999): Varicocele is associated with elevated spermatozoal reactive oxygen species production and diminished seminal plasma antioxidant capacity. J. Urol., 161:1831-1834.

30. Sharma R., Pasqualotto F., Nelson D., Thomas A. Jr, Agarwal A., (1999): The reactive oxygen species- total antioxidant capacity score is a new measure of oxidative stress to predict male infertility. Hum. Reprod., 14: 2801-2807.

31. Huszar G., and Vigue L. (1994): Correlation between the rate of lipid peroxidation and cellular maturity as measured by creatine kinase activity in human spermatozoa. J. Androl., 15:7177.

32. Twigg J., Fulton N., and Gomez E. (1998): Analysis of the impact of intracellular reactive oxygen species generation on the structural and functional integrity of human spermatozoa: lipid peroxidation, DNA fragmentation and effectiveness of antioxidants. Hum. Reprod., 13:1429- 1436. 


\section{تعبير بروتين الصدمة الحرارية و الاجهاد التأكسىى فى عق الرجال}

عادل عبدالقادر زلطة ' ـناريمان كمال بلرالدين' - حسين عبل العزيز عبل الله 'ـ محمود

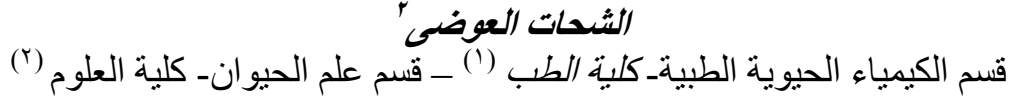

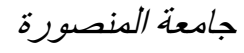

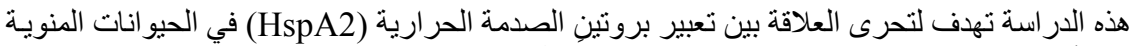

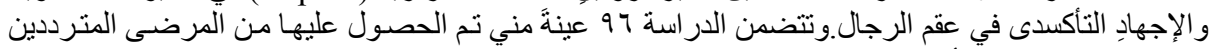

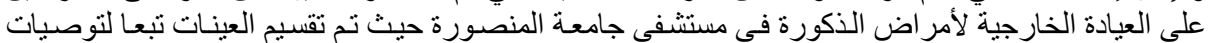

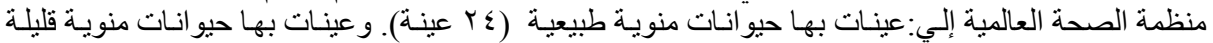

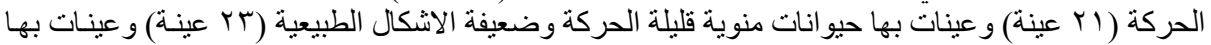

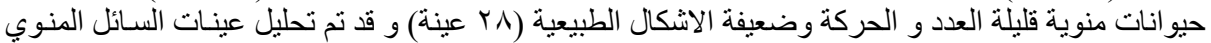

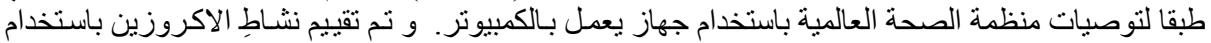

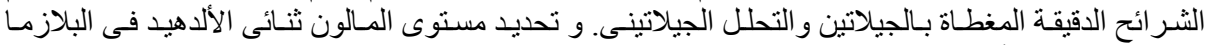

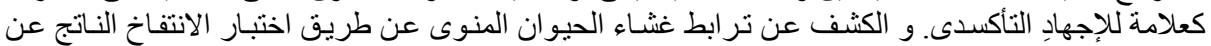

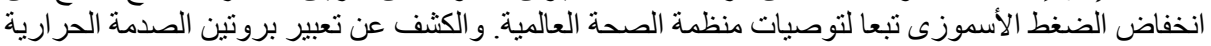

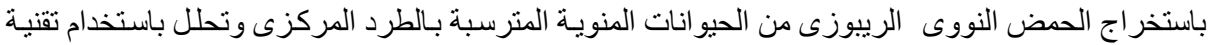

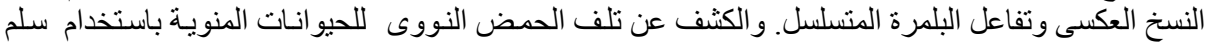

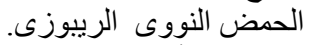

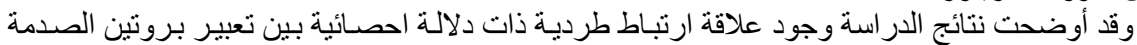

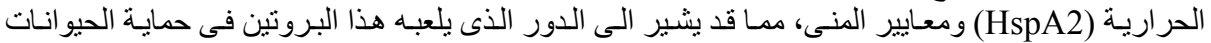

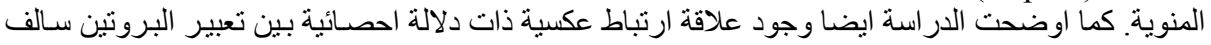

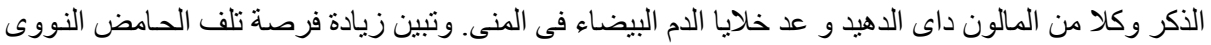
الريبوزى مع انخفاض تعبير البروتين مدل الدراسية.

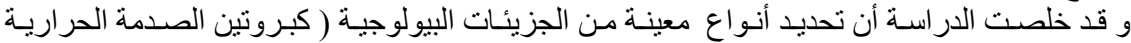

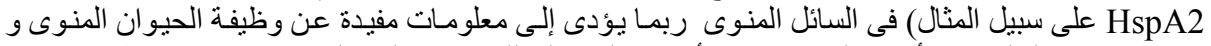

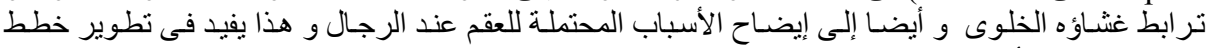
علاجية موجهة لأسباب و طرق حدوث العقى 
